\title{
ECONOMIC FACTORS IN THE DEVELOPMENT AND APPLICATION OF UAV'S AND THE FIGHT WITH WILD FIRES
}

\author{
Teodora Petrova ${ }^{1}$ and Zhivo Petrov ${ }^{2}$ \\ ${ }^{1}$ Assist. Prof. Ph.D., Georgi Benkovski Air Force Academy, Dolna Mitropoliya, Bulgaria, \\ teodorapetrova33@abv.bg \\ ${ }^{2}$ Assist. Prof. Ph.D., Georgi Benkovski Air Force Academy, Dolna Mitropoliya, Bulgaria, \\ zhpetrov@gmail.com
}

\begin{abstract}
According to experts from "Teal Group" over the next ten years the space industry will grow increasingly fast in the UAV segment. UAV development and production costs will almost double: if the annual cost of the UAV market in 2008 was estimated at $\$ 3.4$ billion then in 2017 it would increase to $\$ 7.3$ billion. The main reason for the rapid development in the UAV's global market is the US strategy to supply troops with hightech systems that enable information and network-oriented military operations. At the same time, UAVs are considered as promising means for next-generation intelligence and attacks.
\end{abstract}

Keywords: economical aspects, unmanned aerial vehicles, integration of UAV's, unified airspace.

\section{INTRODUCTION}

The military middle-range unmanned aerial vehicle (UAV) integration with a long active exploitation status (MALE) will allow the conditions to be prepared for heavy civil UAV use in the unsegregated air space. Working on this conception will provide the unprecedented impetus for the European web digitalization and automatization for air space management (ASM), which must be implemented for the project SESAR, so effective and secured exploitation to be provided both for navigated manned and unmanned aerial vehicles in the shared air space. The solvation of such tasks based on applying revolutionary technologies will not only succeed but will overcome the ambitioned tasks which The European Union established in the general plan for the ASM according to the approved document "Single European Sky High - Level Goals" (Antonov, Tsonev, 2016).

\section{ECONOMIC ASPECTS OF UAV DEVELOPMENT AND APPLICATION}

Important conditions, restricted by the UAV implementation, are the comparatively "wide range" time parameters and the financial costs for the whole process of UAV development. For example, for the UAV RQ-4Global Hawk development there have been spent approximately 205 million USD and the whole project time was for 41 months. But the United States of America annually spends on supplying with unmanned aerial vehicles and their operating systems approximately half a billion USD. If we consider the trends in sector development, then, according to the expert's opinion, during the period of five years (2009 - 2013), there have been observed permanent increase of the unmanned aerial vehicles need of use, based on their rapid commercial use (Antonov, Hristozov, 2017). Lately, the engineer constructors of UAV pay much more attention and effort for the increasing of air space fly duration of the UAV devices. Also, Israel uses for the same purpose 3D printers for UAV different mechanical parts production. 
The unmanned aerial vehicle market development is encouraged mainly by their rapid practical use in local and regional conflicts (Afghanistan and Iraq), a small average of exploitation costs in comparison with manned aerial vehicles, and also with the increasing costs for experimental research and perspective development of the UAV, together with the discovering of new fields of their application.

Although the common understanding of the benefits and the strong sights of UAV application use, they are not so widely distributed in the all different sectors of the armed forces and are not enough integrated into the structures of the armed forces. The reasons for this are many and from different kinds, but some of them can be summarized as:

- The traditional conservatism. The established order prevents the new military systems conceptions development. The armed forces often focus on the specialized systems without paying attention to the multifunctional abilities of many UAVs, which allows their practical use for solving problems in different kinds of armed forces (AF) and at the same time leading up to financial costs decreasing, according to their implementation. In such cases, one kind of armed forces will be able to use multifunctional UAV as well as will be able to supply opportunities for quick access to scout information, received from the Ministry of Defense. (Antonov, 2017a; Terziev, Bankov, Georgiev, 2018);

- An investment competition with other spy developers. The UAVs are a comparatively new innovation for the AF as a type of "weapon", which must survive to the rapid investment competition with the existing systems of armed forces and weapons and all the new models of such kinds that are traditionally and practically used in the AF structures;

- Failed to start syndrome. The unsuccessful results at the beginning of the new military program realization process often lead to following collapse and funds redistribution in favor of another military activity program which is probably more compromising but at the same time, this process results in many unfinished developments in the sphere of UAV. Such cases naturally add more years of AF equipment supply delays with unmanned aerial vehicles;

- Radio channels restriction for the broadcasting of information decreases the effectiveness. In addition, the problems with the operative compatibility and the image processing are slowing down the video casting speed, which is an obstacle for the quick UAV implementation. This is especially important for the tactical level of the armed forces (at a battalion level and below);

- The high price, the many accidents, the system's unreliability at the beginning and low activity regime time duration. The UAV price is unexpected higher. Also, UAVs have a significantly high level of accidents because of navigator's mistakes or subsystems damages. Also, they have a much lower ability of survival in comparison with the pilot navigating airplanes.

The basic reasons for the losses can be classified as followed: engine problems - $37 \%$, navigation system management problems $-25 \%$; operator's mistakes $-17 \%$, communication problems $-11 \%$, others $-14 \%$.

During the last world military conflicts, the practical experience clearly demonstrated the advantages of such UAV systems and established new conceptions for their practical use for the military forces (Stoev, Zaharieva, Mutkov, 2019; Terziev, Bankov, Georgiev, 2018a). The expanding the reach of the UAV military use is mostly connected with the accelerating of their system's implementation which often are even at a final stage of production.

In order to accelerate the UAV investigations for the AF, it is necessary to follow the next recommendations:

- The new platforms must be sequenced with the demands based on the predicted needs of the future operations;

- The supplied for armed forces purposes UAVs in every AF subdivision must be estimated for the practical usage and by the other types of AFs. New developments must be provided only if it is impossible the demanded effect to be achieved while using the existing systems;

- The managing systems improving, control and communication management (by analogy with Command, Control and Communication of the USA), and also, the systems of information processing must be in answer with the UAV development and the AF equipment.

The USA, France, Sweden and many other west countries are trying to increase the practical use efficiency of military UAV and the aviation weapons in order to decrease the equipment and pilots lost, and also the human resources costs to be decreased together with all the spending for the exploitation and maintenance. One of the basic work directions is focused on the implementation of the armed UAV and mostly for the specific specialized armed UAV for multiple use and which are intended for detection, identification and distraction of ground and mobile targets, fire suppression of the enemy ASD (air space defense), and for the long term strategy plan - also the fighting with the air force targets. That UAV is characterized with a low level of visibility in the optical and radiolocation range, their combat radius of the range is comparative with 
the contemporary tactical fighters with much fewer characteristics according to weight to size ratio, they are characterized with a high level of maneuverability and hull durability. The basic requirements according to them include also a comparatively low level of cost productions, easy maintenance, and exploitation (Stoev, Zaharieva, Borodzhieva, 2019a; Terziev, Petkova - Georgieva, 2019b-c). In the category for fighting purposes UAV the experts include both the traditional armed and the reconnaissance shock apparatus with maximum weight on departure up to $200 \mathrm{~kg}$. In the future are recommended some opportunities for management guided armed weapons from different types, including perspective contemporary small aviation bombs 1-250 SSB and aviation ammunitions LOCAAS with an active laser targeting. Guided missiles are used AIM-9 "Sidewinder" from "air - to- air" class with wide range of height and speed of the fields with tracing target the same like from an own on-board technique, as well with other UAV or fighting airplanes and helicopters.

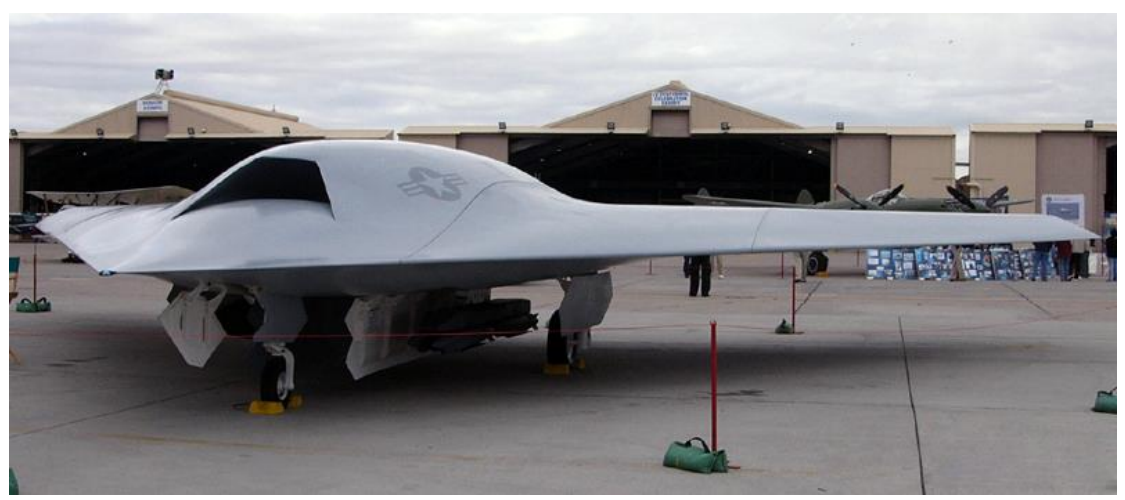

Fig. 1: UAV X - 45 from Boeing Company

The developed UAV X-45 from Boeing Company with collaboration with the Union for modern investigations of the Ministry of Defense and the USA ASD is very promising and perspective combatant UAV. That UAV X45 uses a powerful engine which fully covers the specification for the tactical-technical requirements of supplying high around the sound speed of the fighting areas (fig. 1).

The main onboard radioelectric and technical equipment consists of radiolocation station with phaser antenna grid, an active laser locational complex, infrared station for front survey, video cameras, equipment for radioelectric reconnaissance, communications, navigation, and a defense recognition system ("save or enemy"), a weapon guidance system. The different kinds of weapons that can be used on the UAV X-45 board are, as followed:

- Guiding navigation bombs from the JDAM series with different caliber;

- Small bombs from 1 to $250 \mathrm{~kg}$;

- Guided missiles „Hellfire“ with semi-active laser or active radiolocation self-directing combat head (GOS);

- Guiding ammunitions LOCAAS, undetectable for the radiolocation stations missiles and other means of destructions, as well as autonomous targets ADM-160 and equipment containers for a radioelectric fight.

In accordance with the accomplishing task, the arming and the outer boarding tanks can be placed on both into the inner space sections and into the wings space. In order to increase the time of the flight duration at a self-based search or when it is necessary to increase the combat range of action, the UAVs are supplied with a system for fuel charging during flight time. For the UAV's flight control, it is used a station for guidance, which can be situated on the ground, in the air or on a ship. For instructions and information receiving there are included satellite communicational systems, some other UAVs or even re-translator airplanes. The UAVs can be used at semi-automatic or autonomy regime, as the inertial navigation system is used with data correction according to the space radio-navigational system NAVSTAR. In cases of a partial or total loss of communication with the UAV, it is possible to be carried on the autonomy flight that is settled in advance for fulfilling a target rout. In this case, the regime is "ready for commands" or starting a program for self-deleting of all the instructions about the combat targets and returning back to the military airport base ((Terziev, Arabska, Dzhumalieva, 2016a; Terziev, Dzhumalieva, 2015; Nichev, 2009; Terziev, Dzhumalieva, 2016b-e; Stoykov, 2011-a; Stoykov, 2002; Stoykov, 2003; Stoykov, 2005).

\section{CONCLUSION}

According to the experts' investigation from the analytical company "Teal Group", during the next ten years, the space industry will develop most rapidly in the sector UAV. The UAV development and production costs 
will almost double: if the annual amount of the UAV market during 2008 was estimated to 3,4 billion USD, nowadays (2017-2019) it has been increased up to 7,3 billion USD. The main reason for the rapid development of the UAV world market is the American strategy for supplying the military forces with high technology systems that give opportunities to provide informational and net oriented combat actions. At the same time, the UAVs are considered a promising and prospective military opportunity for reconnaissance and attacks from the next generation (Terziev, Bogdanova, Kanev, Georgiev, 2019b-d; Petrov, Georgiev, 2019e; Terziev, Georgiev, 2017b; Terziev, Nichev, 2017c-i; Terziev, Nichev, Bogdanov, 2017j-k; Terziev, Madanski, Georgiev, 2017l-m).

\section{REFERENCE LIST}

Antonov, S., Hristozov, I. (2017). Otsenka na vazmozhnostite na polevite sistemi za komandvane i upravlenie za poddarzhane na eksploatatsiyata na vaorazhenieto i tehnikata, Sbornik dokladi ot godishnata nauchna konferentsiya na fakultet "Natsionalna sigurnost i otbrana" - "Savremenni predizvikatelstva pred sigurnostta i otbranata”, Parva chast, Sofiya, Voenna akademiya "Georgi Stoykov Rakovski“, 2017, str. 99-104, ISBN 978-954-9348-92-7 (Антонов С., Христозов И. Оценка на възможностите на полевите системи за командване и управление за поддържане на експлоатацията на въоръжението и техниката, Сборник доклади от годишната научна конференция на фракултет „Национална сигурност и отбрана“ - "Съвременни предизвикателства пред сигурността и отбраната”, Първа част, София, Военна академия „Георги Стойков Раковски“, 2017, стр. 99-104, ISBN 978-954-9348-92-7).

Antonov, S. I., Tsonev, T., (2016). Possibilities for automation of designing elements of small arms using CAD/CAM/CAE systems”,Collection of papers: „Defense And Security, Mechanical Engineering And Military Technology, Communication And Computing Technologies, Social Science“, Shumen, Bulgaria 2016, p.p. 319-324, "Vasil Levski” National Military University - Artillery, Air Defense and CIS Faculty, Shumen, Bulgaria, ISSN 2367-7902.

Antonov, S. (2017a). Comparative analysis of the armament and equipment support modules in the field of command and control information systems of NATO armies, International Scientific Journal "SECURITY \& FUTURE", Year I, Issue 4, 2017, pp. 163-167, WEB ISSN 2535-082X; PRINT ISSN 2535-0668.

Stoev, I., Zaharieva, S., Mutkov, V., (2019). Evaluation of Gross Errors in Measured Temperature with an Electronic System for Management of Residential Energy Systems, International Scientific Conference 27th Telecommunications Forum, ISBN: 978-1-7281-4789-5, pp 454-457.

Stoev, I., Zaharieva, S., Borodzhieva, A., (2019a). An Approach for Assessment of the Synchronization Between Digital Temperature Sensors, International Scientific Conference 27th Telecommunications Forum, ISBN: 978-1-7281-4789-5, pp 458-461.

Terziev, V., Bankov, S., Georgiev, M. (2018). The Change in the approach of the court of justice of the European Union in the context of market freedoms and internal situations. // Journal of Innovations and Sustainability, Plovdiv, Bulgaria, 4, 2018, 3, pp. 85-112, ISSN 2367-8127 (CD-ROM), ISSN 23678151 (on-line).

Terziev, V., Bankov, S., Georgiev, M. (2018a). The Stability and growth pact: pursuing sound public finances and coordinating fiscal policies in the EU member states. // Journal of Innovations and Sustainability, Plovdiv, Bulgaria, 4, 2018, 3, pp. 53-68, ISSN 2367-8127 (CD-ROM), ISSN 2367-8151 (on-line).

Terziev, V., Petkova - Georgieva, S. (2019b). The performance measurment system key indicators and the determinants impact on the level of decentralization using as an example a subdivisional unit from the Bulgarian social health and care experience. // Proceedings of SOCIOINT 2019-6th International Conference on Education, Social Sciences and Humanities 24-26 June 2019- Istanbul, Turkey, International Organization Center of Academic Research, Istanbul, Turkey, 2019, pp. 515-524, ISBN: 978-605-82433-6-1.

Terziev, V., Petkova - Georgieva, S. (2019c) A research study of nonlinearity experiencing in the rate of current account deficit to the Bulgarian health and care national product. // Proceedings of SOCIOINT 2019- 6th International Conference on Education, Social Sciences and Humanities 24-26 June 2019Istanbul, Turkey, International Organization Center of Academic Research, Istanbul, Turkey, 2019, pp. 525-533, ISBN: 978-605-82433-6-1. 
Terziev, V., Arabska, E., Dzhumalieva, A. (2016a). Dostapnost do pazara na truda i sotsialna adaptatsiya na osvobodenite ot balgarskata armiya voennosluzheshti i chlenovete na tehnite semeystva. // Nauchna konferentsiya na tema „Zashtita ot diskriminatsiya v Balgariya i Evropa“ po sluchay Denya na pravata na choveka, organizirana savmestno ot Akademiyata na MVR i Instituta za darzhavata i pravoto na BAN, Sbornik dokladi ot nauchna konferentsiya, AMVR, 10-11 dekemvri 2015 g., Sofiya, 2016 g., Reg. № URI 4581r - 2926/ 24.03.2016 g. na AMVR, str.16-33, ISBN 978-954-348-136-1 (Терзиев, B., Арабска, Е., Джумалиева, А. Достъпност до пазара на труда и социална адаптация на освободените от българската армия военнослужещи и членовете на техните семейства. // Научна конференция на тема „Защита от дискриминация в България и Европа“ по случай Деня на правата на човека, организирана съвместно от Академията на МВР и Института за държавата и правото на БАН, Сборник доклади от научна конференция, АМВР, 10-11 декември 2015 г., София, 2016 г., Рег. № УРИ 4581р - 2926/ 24.03.2016 г. на AMBP, стр.16-33, ISBN 978954-348-136-1).

Terziev, V., Dzhumalieva, A. (2015). Religiyata i vyarata v konteksta na vaprosa za zashtita ot diskriminatsiya. // Nauchna konferentsiya na tema "Zashtita ot diskriminatsiya v Balgariya i Evropa“ po sluchay Denya na pravata na choveka, organizirana savmestno ot Akademiyata na MVR i Instituta za darzhavata i pravoto na BAN, 10-11 dekemvri 2015 g., Sofiya, ISBN 978-954-348-136-1 (Терзиев, B., Джумалиева, А. Религията и вярата в контекста на въпроса за защита от дискриминация. // Научна конференция на тема „Защита от дискриминация в България и Европа“ по случай Деня на правата на човека, организирана съвместно от Академията на МBP и Института за държавата и правото на БАН, 10-11 декември 2015 г., София, ISBN 978-954-348-136-1).

Nichev, N. (2009). Historical analysis of the involvement of joint armed forces in humanitarian operations. 15th International Conference on Knowledge-Based Organization 26-28 Nov 2009: Military Sciences. Security and Defense, Conference Proceedings 1, Volume: 1, Pages: 104-108, Sibiu, Romania, 2009.

Terziev, V., Dzhumalieva, A. (2016b). Po nyakoi vaprosi otnosno diskriminatsiyata po priznak „pol” vav vrazka s gavkavite formi na zaetost. // Nauchna konferentsiya na tema "Zashtita ot diskriminatsiya v Balgariya i Evropa" po sluchay Denya na pravata na choveka, organizirana savmestno ot Akademiyata na MVR i Instituta za darzhavata i pravoto na BAN, Sbornik dokladi ot nauchna konferentsiya, AMVR, 10-11 dekemvri 2015 g., Sofiya, 2016 g., Reg. № URI 4581r - 2926/ 24.03.2016 g. na AMVR, str.2-15, ISBN 978-954-348-136-1 (Терзиев, В., Джумалиева, А. По някои въпроси относно дискриминацията по признак „пол” във връзка с гъвкавите форми на заетост. // Научна конференция на тема „Защита от дискриминация в България и Европа“ по случай Деня на правата на човека, организирана съвместно от Академията на МВР и Института за държавата и правото на БАН, Сборник доклади от научна конференция, АМВР, 10-11 декември 2015 г., София, 2016 г., Рег. № УРИ 4581р - 2926/ 24.03.2016 г. на AMBP, стр.2-15, ISBN 978954-348-136-1).

Terziev, V., Dzhumalieva, A. (2016c). Diskriminatsiyata po priznak: pol vav vrazka s prilaganeto na gavkavite formi na zaetost na natsionalniya pazar na truda. // XI Mezhdunarodnoy nauchnoy konferentsii „Innovatsii v tehnologiyah i obrazovanii", 18-19 Marta 2016 g., Kuzbasskiy gosudarstvennayy tehnicheskiy universitet im. T.F. Gorbacheva, Belovo, 4, 2016, ISBN 978-5-906888-04-4, s.219-233 (Терзиев, В., Джумалиева, А. Дискриминацията по признак: пол във връзка с прилагането на гъвкавите форми на заетост на националния пазар на труда. // XI Международной научной конференции „Инновации в технологиях и образовании", 18-19 Марта 2016 г., Кузбасский государственный технический университет им. Т.Ф. Горбачева, Белово, 4, 2016, ISBN 978-5906888-04-4, c.219-233).

Terziev, V., Dzhumalieva, A. (2016d). Dostapnost do pazara na truda i sotsialna adaptatsiya na osvobodenite ot balgarskata armiya voennosluzheshti i chlenovete na tehnite semeystva. // XI Mezhdunarodnoy nauchnoy konferentsii „Innovatsii v tehnologiyah i obrazovanii", 18-19 Marta 2016 g., Kuzbasskiy gosudarstvennayy tehnicheskiy universitet im. T.F. Gorbacheva, Belovo, 4, 2016, ISBN 978-5-906888-04-4, s.233-253 (Терзиев, В., Джумалиева, А. Достьпност до пазара на труда и социална адаптация на освободените от българската армия военнослужещи и членовете на техните семейства. // XI Международной научной конференции „Инновации в технологиях и образовании", 18-19 Марта 2016 г., Кузбасский государственный технический университет им. Т.Ф. Горбачева, Белово, 4, 2016, ISBN 978-5-906888-04-4, с.233-253).

Terziev, V., Dzhumalieva, A. (2016e). Po nyakoi vaprosi na religiyata i vyarata v konteksta na vaprosa za zashtita ot diskriminatsiya. // XI Mezhdunarodnoy nauchnoy konferentsii „Innovatsii v tehnologiyah i 
obrazovanii", 18-19 Marta 2016 g., Kuzbasskiy gosudarstvennayy tehnicheskiy universitet im. T.F. Gorbacheva, Belovo, 4, 2016, ISBN 978-5-906888-04-4, s.253-261 (Терзиев, В., Джумалиева, А. По някои въпроси на религията и вярата в контекста на въпроса за защита от дискриминация. // XI Международной научной конференции „Инновации в технологиях и образовании", 18-19 Марта 2016 г., Кузбасский государственный технический университет им. Т.Ф. Горбачева, Белово, 4, 2016, ISBN 978-5-906888-04-4, с.253-261).

Stoykov, Mitko. (2011). Crisis and emergency response capabilities - Republic of Bulgaria, NATO Advanced Research Workshop on Sustained Emergency Relief - Regionally Developed Capacities, IOS Press, Nieuwe Hemweg 6B, 1013 BG Amsterdam, Netherlands, Web of Science, Proceedings Paper, ID: WOS:000351360000016, ISBN:978-1-61499-315-5; 978-1-61499-314-8, ISSN: 1879-8268, pp.: 5968 Security and Defence http://ebooks.iospress.nl/volumearticle/35344, 2011.

Stoykov, Mitko. (2011a). Development of Crisis Management and Disaster Response Centre of Excellence (CMDR COE) Bulgarian Contribution to NATO Smart Defence, NATO Advanced Research Workshop on Sustained Emergency Relief - Regionally Developed Capacities, IOS Press, Nieuwe Hemweg 6B, 1013 BG Amsterdam, Netherlands, Web Of Science, Proceedings Paper, ID:

WOS:000351360000016, ISBN:978-1-61499-315-5; 978-1-61499-314-8, ISSN: 1879-8268, pp.: 18 24 Security and Defence http://ebooks.iospress.nl/volumearticle/35335; 2011.

Stoykov, Mitko. (2002). Informatsionni resheniya za natsionalnata sigurnost - Mrezhovo-tsentrichnata voyna, Voenen zhurnal, br.6, 2002 g. str. 69-79, ISSN 0861-7392 (Стойков, Митко. Информационни решения за националната сигурност - Мрежово-центричната война, Военен журнал, бр.6, 2002 г. стр. 69-79, ISSN 0861-7392).

Stoykov, Mitko. (2003). Neobhodimost ot promeni v planiraneto na otbranata - paketirane na potentsialnite vazmozhnosti na misiite, Voenen zhurnal, br. 1, 2003 g. str 102-112, ISSN 0861-7392 (Стойков, Митко. Необходимост от промени в планирането на отбраната - пакетиране на потенциалните възможности на мисиите, Военен журнал, бр. 1, 2003 г. стр 102-112, ISSN 0861-7392).

Stoykov, Mitko. (2005). Transformirashto liderstvo na transformatsiyata na sistemata za sigurnost, Voenen zhurnal, br. 2, 2005 g. str. 16-35, ISSN 0861-739 (Стойков, Митко.Трансформиращо лидерство на трансформацията на системата за сигурност, Военен журнал, бр. 2, 2005 г. стр. 16-35, ISSN 0861-739).

Terziev, V., Bogdanova, M., Kanev, D., Georgiev, M. (2019b). The cadets and the reasons for their drop-out of the National Military University. // Proceedings of ADVED 2019 - 5th International Conference on Advances in Education and Social Sciences, 21-23 October 2019, International Organization Center of Academic Research, Istanbul, Turkey, 2019, pp. 398-406, ISBN: 978-605-82433-7-8.

Terziev, V., Bogdanova, M., Kanev, D., Georgiev, M. (2019c). The cadets from the military schools as subjects of educational activity. // Proceedings of ADVED 2019 - 5th International Conference on Advances in Education and Social Sciences, 21-23 October 2019, International Organization Center of Academic Research, Istanbul, Turkey, 2019, pp. 407-418, ISBN: 978-605-82433-7-8.

Terziev, V., Bogdanova, M., Kanev, D., Georgiev, M. (2019d). Uses of the strategic card in the republic of Bulgaria's land forces. // Proceedings of ADVED 2019 - 5th International Conference on Advances in Education and Social Sciences, 21-23 October 2019, International Organization Center of Academic Research, Istanbul, Turkey, 2019, pp. 519-525, ISBN: 978-605-82433-7-8.

Petrov, N., Georgiev, M. (2019e). Assessing of the military professional competencies. // Proceedings of SOCIOINT 2019- 6th International Conference on Education, Social Sciences and Humanities 24-26 June 2019- Istanbul, Turkey, International Organization Center of Academic Research, Istanbul, Turkey, 2019, pp. 462-472, ISBN: 978-605-82433-6-1.

Terziev, V., Georgiev, M. (2017b). Highlights of the evolution of the „balanced scorecard” idea as a model for managing strategy development and control. // Proceedings of SOCIOINT 2017- 4th International Conference on Education, Social Sciences and Humanities 10-12 July 2017- Dubai, UAE, 2017, ISBN: 978-605-82433-1-6, pp.607-610.

Terziev, V., Nichev, N. (2017c). Streamlining management solutions for economic, effective and efficient spending of resources for security and defense. // Proceedings of SOCIOINT 2017- 4th International Conference on Education, Social Sciences and Humanities 10-12 July 2017- Dubai, UAE, 2017, ISBN: 978-605-82433-1-6, pp.667-671.

Terziev, V., Nichev, N. (2017d). Some aspects on forming preparedness of logistics military officers for 
management activities. // Proceedings of SOCIOINT 2017- 4th International Conference on Education, Social Sciences and Humanities 10-12 July 2017- Dubai, UAE, 2017, ISBN: 978-605-82433-1-6, pp.631-635.

Terziev, V., Nichev, N. (2017e). Research, Identification and monitoring of the needs of occupational training of social activities experts. // Proceedings of SOCIOINT 2017- 4th International Conference on Education, Social Sciences and Humanities 10-12 July 2017- Dubai, UAE,2017, ISBN: 978-60582433-1-6, pp.556-574.

Terziev, V., Nichev, N. (2017f). Model of methodology for determining the needs of continuing vocational training of social work specialists providing social services. // Proceedings of SOCIOINT 2017- 4th International Conference on Education, Social Sciences and Humanities 10-12 July 2017- Dubai, UAE, 2017, ISBN: 978-605-82433-1-6, pp.541-555.

Terziev, V., Nichev, N. (2017g). Strategic framework for social entrepreneurship development in Bulgaria. // Proceedings of SOCIOINT 2017- 4th International Conference on Education, Social Sciences and Humanities 10-12 July 2017- Dubai, UAE, 2017, ISBN: 978-605-82433-1-6, pp.531-540.

Terziev, V., Nichev, N. (2017h). Main features of the offsets in defense trade. Proceedings of SOCIOINT 2017- 4th International Conference on Education, Social Sciences and Humanities 10-12 July 2017Dubai, UAE, 2017, ISBN: 978-605-82433-1-6, pp.661-666.

Terziev, V., Nichev, N. (2017i). Analysis of the environment for military educational system functioning and its impact on the preparation of cadets for military professional activities in the republic of Bulgaria. // Proceedings of SOCIOINT 2017- 4th International Conference on Education, Social Sciences and Humanities 10-12 July 2017- Dubai, UAE, 2017, ISBN: 978-605-82433-1-6, pp.627-630.

Terziev, V., Nichev. N., Bogdanov, P. (2017j). Comparative analysis of the formation of military professional skills in the cadets to be trained in logistics specializations. // Proceedings of ADVED 2017- 3rd International Conference on Advances in Education and Social Sciences 9-11 October 2017- Istanbul, Turkey, 2017, ISBN: 978-605-82433-0-9, pp.671-677.

Terziev, V., Nichev, N., Bogdanov, P. (2017k). Prospects for development of higher education in Bulgaria. // Proceedings of ADVED 2017- 3rd International Conference on Advances in Education and Social Sciences 9-11 October 2017- Istanbul, Turkey, 2017, ISBN: 978-605-82433-0-9, pp.678-689.

Terziev, V., Madanski, V., Georgiev, M. (2017I). Offset implementation impact on technology transfer in Bulgaria. // Proceedings of ADVED 2017- 3rd International Conference on Advances in Education and Social Sciences 9-11 October 2017- Istanbul, Turkey, 2017, ISBN: 978-605-82433-0-9, pp.743-747.

Terziev, V., Madanski, V., Georgiev, M. (2017m). Offset as an economic operation and a trade practice. // Proceedings of ADVED 2017- 3rd International Conference on Advances in Education and Social Sciences 9-11 October 2017- Istanbul, Turkey, 2017, ISBN: 978-605-82433-0-9, pp.748-753. 